doi: 10.32620/oikit.2021.94.08

УДК 539.401:539.23:620.3

О. В. Шорінов

\title{
Оцінювання рівня термічних напружень в оксидних тонких плівках
}

\author{
Національний аерокосмічний університет ім. М.Є. Жуковського \\ "Харківський авіаційний інститут»
}

\begin{abstract}
Надано результати оцінювання характеру і величини залишкових термічних напружень в оксидному шарі $\mathrm{CuO}$, синтезованому на підкладці з чистої міді за допомогою відомої аналітичної моделі розрахунку термічних напружень в одношарових покриттях. Термічні напруження можуть призвести до виникнення деформацій і руйнування тонкоплівкових структур і покриттів, браку та зниженю якості деталей, на які вони нанесені. Головним технологічним параметром, від якого залежать величини термічних напружень, є робочі температури процесу формування тонкоплівкових оксидних шарів. Після завершення процесу синтезу підкладки з покриттями охолоджуються до температури навколишнього середовища. Це охолодження призводить до виникнення термічних залишкових напружень. У випадку, коли величина коефіцієнта термічного розширення матеріалу оксидного шару значно менша за величину коефіцієнта термічного розширення матеріалу підкладки, в першому випадку виникають стискальні залишкові напруження, а в останньому - розтягальні. Було досліджено напружено-деформований стан під час охолодження системи покриття-підкладки, вільної від дії зовнішніх сил. В математичній моделі було використано припущення, що виникаючі деформації не перевищують межі пружності, тобто залишкові напруження лежать в області пружних деформацій, а температура по товщині матеріалу не змінюється. Також слід зазначити, що значення коефіцієнтів термічного розширення, модулів пружності та коефіцієнтів Пуассона $\epsilon$ величинами сталими, тобто не залежать від зміни температури. В роботі наведено основні аналітичні залежності термічних напружень від фрізико-механічних властивостей матеріалів покриття і підкладки. За результатами розрахунків побудовано графік залежності термічних напружень системи покриття-підкладка від температури синтезу оксидних шарів. Термічні напруження $€$ однією із складових сумарних залишкових напружень, що діють у системі тонка плівка / покриття. Отримані результати щодо значень залишкових напружень можуть бути використані для попередження руйнування тонких плівок і покриттів, а також прогнозування характеристик поверхневих шарів.
\end{abstract}

Ключові слова: оксидний шар, залишкові напруження, коефіцієнт термічного розширення, покриття

\section{Вступ}

У цей час тонкоплівкові структури і покриття широко застосовуються в різних галузях промисловості. Серед способів отримання тонкоплівкових структур і покриттів можна виділити магнетронне розпилювання [1], методи, засновані на використанні плазми [2], газотермічні методи напилювання, наприклад, плазмове [3], холодне газодинамічне [4] та ін. Тонкоплівкові структури і покриття використовуються для підвищення стійкості різального інструменту із застосуванням зносостійких покриттів [5]. Особливу увагу необхідно приділити застосуванню тонкоплівкових структур у виробництві виробів електронної техніки [6]. Розвиток технологій формування наноструктур відкриває нові можливості у проєктуванні високоякісної і нестандартної апаратури, напівпровідникових інтегральних схем та інших.

Незалежно від способу та призначення покриттів і плівок, найважливішим показником $€$ адгезійна міцність, яка визначає надійність і працездатність виро- 
бу, на якому вони отримані. Адгезія є дуже складним явищем, що залежить від великої кількості технологічних параметрів процесу їх фрормування. Після завершення процесу покриття і плівки знаходяться у напруженому стані, а самі залишкові напруження прагнуть до релаксації. Напруження та адгезійна міцність у значній мірі визначають той чи інший механізм, що буде реалізовано для їх релаксації.

Напруження можуть бути стискальними і розтягальними [7]. Якщо певні граничні значення значно перевищенні, то це може призвести до деформації та руйнування тонкоплівкових структур і покриттів. Міцне зчеплення покриття на тонких і гнучких підкладках може призвести до їх вигину, а в разі слабкої адгезії може статися крайове відшарування. Стискальні напруження є джерелом здуття та гофрування покриттів, а розтягальні - призвести до їх розтріскування [8].

Сумарне напруження системи покриття-підкладка визначається трьома складовими: структурною, термічною і складовою, яка враховує зовнішні впливи [8]. Метою роботи $\epsilon$ аналіз термічної складової і оцінювання величини термічних напружень, що виникають під час формування оксидних структур на прикладі $\mathrm{CuO}$, синтезованих на підкладках з міді.

\section{1. Аналіз методів визначення термічних напружень}

Для запобігання деформацій і руйнування тонкоплівкових структур і покриттів необхідно знати величину та розподіл термічних залишкових напружень у системі покриття-підкладка. Наразі опубліковано багато робіт, спрямованих на розроблення методів визначення залишкових напружень та вивченню природи їх виникнення залежно від різних фракторів [9]. Проте у зв'язку з багатофракторністю процесів і причин, що впливають на утворення залишкових напружень, не існує єдиної математичної моделі, що враховувала б усі фрактори або хоча б намагалася це зробити. Окрім того, багато аспектів прогнозування та керування характером і знаком напружень залишаються відкритими, особливо в галузі отримання оксидних наноструктур [10].

У багатьох методах отримання покриттів і тонких плівок температура процесу $є$ одним з основних фракторів, що впливає на формування фрізикомеханічних та експлуатаційних властивостей покриттів. У деяких випадках температура впливає на інтенсифрікацію процесів зростання покриттів і тонких плівок [11, 12]. Беззаперечним $€$ фракт впливу робочих температур процесу на утворення термічних залишкових напружень в покриттях і підкладках, що виникають під час охолодження системи після завершення процесу фрормування покриттів, а також температур експлуатації виробів з покриттями [13].

Аналізуючи існуючі методи визначення залишкових напружень, що діють у тонких плівках і покриттях, можна бачити, що не має прямого методу їх визначення. Різні розрахунково-експериментальні методи подані в роботі [8]. Визначення напружень здійснюється опосередковано 3 перерахунком за розробленими рівняннями.

Математичне моделювання процесів формування покриттів та виникнення залишкових напружень набуло поштовху 3 появою сучасних програмних розрахункових комплексів, заснованих на використанні методу скінченних елементів [14]. Різні математичні моделі фрормування залишкових напружень, що виникають під час різних технологічних процесів, значно відрізняються одні від онших за методом побудови та способом їх реалізації. 
Використання комп'ютерної техніки дозволяє визначити розподіл і величину залишкових термічних та механічних напружень, проаналізувати в цілому напружено-деформований стан системи покриття-підкладка та визначити критичні значення.

Окрім експериментальних методів і методів числового моделювання, важливе місце займає використання аналітичних моделей розрахунку залишкових напружень. Для розрахунку термічних залишкових напружень, що виникають через зміну температури навколишнього середовища, було розроблено аналітичні моделі, засновані на класичній теорії згину балки [15]. Для багатошарових покриттів щоб розрахувати напружено-деформований стан через термічні навантаження, зростає і кількість припущень, що $є$ причиною складнощів у розробленні моделі, що буде з достовірною точністю описувати процес. Наприклад, спрощення щодо постійного значення фізико-механічних властивостей матеріалів, які насправді $€$ функцією від температури [16].

Існуючі моделі розрахунку термічних напружень об'єднує те, що всі вони грунтуються на використанні рівняння Стоуні [17]. У процес дослідження тонкоплівкових структур, коли товщина покриття значно менша за товщину підкладки, деформаціями підкладки можна знехтувати, а рівнянням термічних напружень пов'язати кривизну системи з тепловим навантаження на покриття. Зі збільшенням співвідношення товщини покриття до товщини підкладки градієнти напружень стають все більш значущими, та постає питання введення характеристичного критерію в рівняння [18].

Моделі, що описують термічно-напружений стан одношарових, багатошарових покриттів із градієнтом властивостей, композиційних покриттів, а також багатошарових покриттів з проміжним шаром із градієнтом властивостей, подані в роботі [19].

\section{2. Математична модель розрахунку термічних напружень в одношарових покриттях та тонких плівках}

Нижче подано аналітичну модель, яка була використана в дослідженні для розрахунку термічних напружень [19]. Причиною термічних напружень під час формування покриттів $€$ охолодження системи покриття-підкладка від температури напилювання або $T_{D}$ до температури навколишнього середовища $T_{R}$. Значні відмінності коефіцієнтів термічного розширення (КТР) матеріалів тонкоплівкової структури та підкладки призводить до виникнення термічних залишкових напружень - розтягальних при $\alpha_{c} \geq \alpha_{s}$ і стискальних при $\alpha_{c} \leq \alpha_{s}$.

На рисунку 1 показана система покриття-підкладка для розрахунку стискальних термічних напружень під час ії охолодження після завершення процесу напилювання за умови $\alpha_{c} \leq \alpha_{s}$ та сильної адгезії між покриттям та підкладкою.

Під час формування тонкоплівкових структур і покриттів на межі поділу з підкладкою або між шарами покриття виникають деформації. Деформації, пов'язані з первинним охолодженням системи покриття-підкладка, можна подати таким чином: 


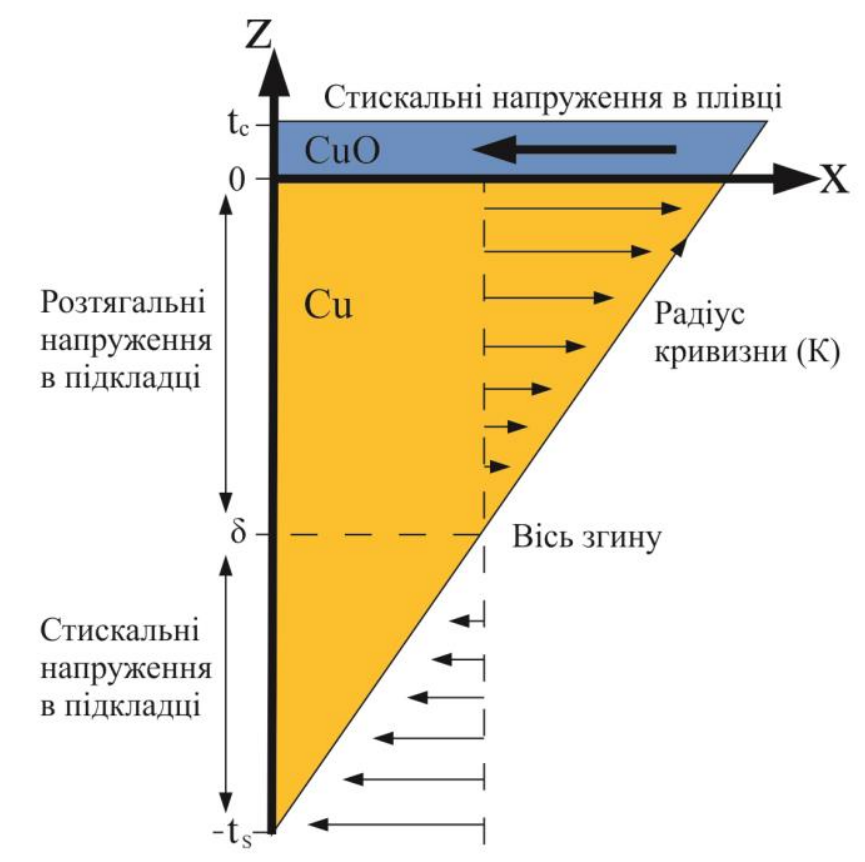

Рис. 1 - Розрахункова схема визначення стискальних термічних напружень системи покриття-підкладка

$$
\Delta \varepsilon=\frac{\sigma_{q}}{E_{c}^{\prime}},
$$

де $\sigma_{q}$ - напруження, що виникають під час охолодження;

$E_{c}^{\prime}$ - ефрективний модуль пружності (модуль Юнга).

У випадку, коли ширина системи покриття-підкладка сумірна 3 їі товщиною, $E_{c}^{\prime}$ дорівнює модулю пружності покриття $\left(E_{c}^{\prime}=E_{c}\right)$. За умови, що $E_{c}^{\prime} \quad$ відповідає біаксіальному модулю плоскої системи, то в цьому випадку $E_{c}^{\prime}=E_{c} /(1-v)$, де $v-$ коефіцієнт Пуассона покриття.

Якщо розглядаються лише термічні напруження, а інші механізми релаксації не враховуються, то деформація $\Delta \varepsilon_{q}$ може бути визначена як:

$$
\Delta \varepsilon_{q} \cong\left(T_{m}-T_{s}\right) \alpha(T),
$$

де $\alpha_{c}(T)$ - КТР, що залежить від температури;

$T_{c}$ - температура покриття;

$T_{s}$ - температура підкладки.

Товщина покриття у разі його збільшення впливає на температуру підкладки. Якщо знехтувати температурним градієнтом покриття, то температуру підкладки можна визначити як

$$
T_{s} \cong T_{c}-q \frac{z}{k}\left(0 \leq z \leq t_{c}\right),
$$


де $q$ і $k$ - коефіцієнт теплопередачі та теплопровідність матеріалу покриття відповідно;

$z$ - координата товщини покриття;

$T_{c}$ - температура шару покриття, що дорівнює температурі процесу $T_{d}$, тобто $T_{c}=T_{d}$ при $z=t_{c}$.

3 аналізу рівняння (3) можна зробити висновок, що у випадку отримання тонкоплівкових структур, коли товщина покриття менша за товщину підкладки, температура підкладки буде майже дорівнювати температурі покриття після завершення процесу підвищення, тобто

$$
T_{s} \cong T_{d} \cong T_{c} \text {. }
$$

Вираз (4) може бути використаний для знаходження термічних залишкових напружень у процесі вторинного охолодження [20]. Під час вторинного охолодження десормація $\Delta \varepsilon_{q}$, що виникає через відмінності фрізичних властивостей матеріалів покриття та підкладки, може бути знайдена як

$$
\Delta \varepsilon_{t}=\int_{T_{s}}^{T_{R}} \alpha_{s}(T) d T-\int_{T_{d}}^{T_{R}} \alpha_{c}(T) d T,
$$

де $\alpha_{S}(T)$ - КТР підкладки;

$T_{R}$ - температура навколишнього середовища.

Після знаходження деформації, можна розрахувати термічні напруження, що виникають у системі покриття-підкладка. Для цього необхідно скласти рівняння балансу сили та моменту. Слід також зазначити, що виникаючі деформації не перевищують межі пружності, тобто залишкові напруження знаходяться в області пружних деформацій.

Для того, щоб описати взаємозв'язок між нормальними напруженнями в покритті $\sigma_{c}$ і підкладці $\sigma_{s}$ та повною деформацією покриття $\varepsilon_{c}$ і підкладки $\varepsilon_{s}$, скористаємося рівняннями

$$
\begin{aligned}
& \sigma_{s}=E_{s}^{\prime} \varepsilon_{s}, \\
& \sigma_{c}=E_{c}^{\prime} \varepsilon_{c},
\end{aligned}
$$

де $E_{s}^{\prime}$ і $E_{c}^{\prime}$ - ефрективні модулі пружності підкладки та покриття відповідно, що можуть бути розраховані як

$$
\begin{aligned}
& E_{c}^{\prime}=\frac{E_{c}}{\left(1-v_{c}\right)} ; \\
& E_{s}^{\prime}=\frac{E_{s}}{\left(1-v_{s}\right)} .
\end{aligned}
$$

Відомим $є$ факт, що повна деформація, яка виникає в шарі покриття та підкладці, складається з деформації, що діє у відповідній площині (підкладці або шарі покриття), і деформації згину [19].

Під дією деформації виникають сили, що діють в площині підкладки та покритті $F_{s}$ і $F_{c}$ відповідно. Рівновісний стан системи покриття-підкладка полягає у тому, що сума діючих сил на систему повинна дорівнювати нулю. Друга складова повної деформації - деформація згину - виникає через 
згинальний момент під дією вищезгаданих сил. Сили, що виникають в результаті деформації згину в підкладці та шарах покриття, призводять до утворення згинального моменту $M$.

В одношарових покриттях для визначення температурних напружень, що виникають через різні значення КТР використано рівняння (5). В роботі [21] для опису радіусуа кривизни системи покриття-підкладка введено критерії $\Sigma$ і $\eta$ :

$$
\Sigma=\frac{E_{c}^{\prime}}{E_{s}^{\prime}}, \eta=\frac{t_{c}}{t_{s}} .
$$

Радіус кривизни можна знайти розв'язавши рівняння

$$
K=-\frac{1}{t_{s}} \frac{6 \sum \eta(\eta+1) \Delta \varepsilon_{t}}{1+4 \Sigma \eta+6 \Sigma \eta^{2}+4 \Sigma \eta^{3}+\Sigma^{2} \eta^{4}} .
$$

3 рівняння видно, що радіус прямо пропорційний деформації $\Delta \varepsilon_{t}$ і зворотно пропорційний товщині підкладки $t_{s}$. Таким чином, термічні остаточні напруження можна подати у вигляді

$$
\begin{aligned}
& \sigma_{t c}=E_{c}^{\prime}\left[\frac{\Delta \varepsilon_{t}}{1+\Sigma \eta}+K(\delta+z)\right]\left(0 \leq z \leq t_{c}\right), \\
& \sigma_{t s}=E_{s}^{\prime}\left[-\frac{\Sigma \eta \Delta \varepsilon_{t}}{1+\Sigma \eta}+K(\delta+z)\right]\left(-t_{s} \leq z \leq 0\right),
\end{aligned}
$$

де $\delta$ - відстань від осі вигину до межі поділу покриття з підкладкою:

$$
\delta=\frac{t_{s}}{2} \frac{1-\Sigma \eta^{2}}{1+\Sigma \eta}
$$

\section{3. Результати розрахунків}

Нижче подано результати розрахунку остаточних термічних напружень для оксидних структур $\mathrm{CuO}$, синтезованих під час нагрівання підкладок з чистої міді в середовищі кисню. Спосіб отримання таких структур описано в роботі [22].

Для розрахунку термічних залишкових напружень були задані наступні робочі температури процесу $T_{D}: 500^{\circ} \mathrm{C}, 600^{\circ} \mathrm{C}$ i $700^{\circ} \mathrm{C}$. Після завершення формування оксидних шарів зразки охолоджувалися до температури навколишнього середовища $T_{R}$, прийнятій $20^{\circ} \mathrm{C}$. Товщина отриманого шару залежить від часу знаходження у камері та прийнята у цьому дослідженні від нуля до 0,1 мм. Товщина мідних підкладок складає 2,0 мм.

Розглянемо систему покриття-підкладка, що складається 3 мідної підкладки та оксидної структури $\mathrm{CuO}$, охолодження якої відбувається при різниці температур $\Delta T=T_{R}-T_{D}$. Напруження в системі виникають лише через різницю температур. Матеріал підкладки має коефіцієнт Пуассона $E_{s}$, КТР $\alpha_{s}$, модуль пружності $v_{s}$, а матеріал покриття має значення $E_{c}, \alpha_{c}$ і $v_{c}$ відповідно. Властивості матеріалів, що використовуються в розрахунках, представлено в таблиці 1 [23]. 
Таблиця 1

Фізико-механічні властивості матеріалів, що було використано в дослідженні

\begin{tabular}{|l|c|c|}
\hline \multirow{2}{*}{\multicolumn{1}{|c|}{ Властивості }} & \multicolumn{2}{c|}{ Матеріал } \\
\cline { 2 - 3 } & Мідна підкладка & Оксидний шар CuO \\
\hline Коефріцієнт термічного розширення & 16,5 & 13,7 \\
\hline Модуль пружності $E, \times 10^{3} \mathrm{MПа}$ & 123,0 & 81,6 \\
\hline Коефіцієнт Пуассона, $v$ & 0,35 & 0,34 \\
\hline
\end{tabular}

Результати розрахунку термічних залишкових напружень у покритті і підкладці залежно від різниці температур $\Delta T$ подано на рисунку 2.

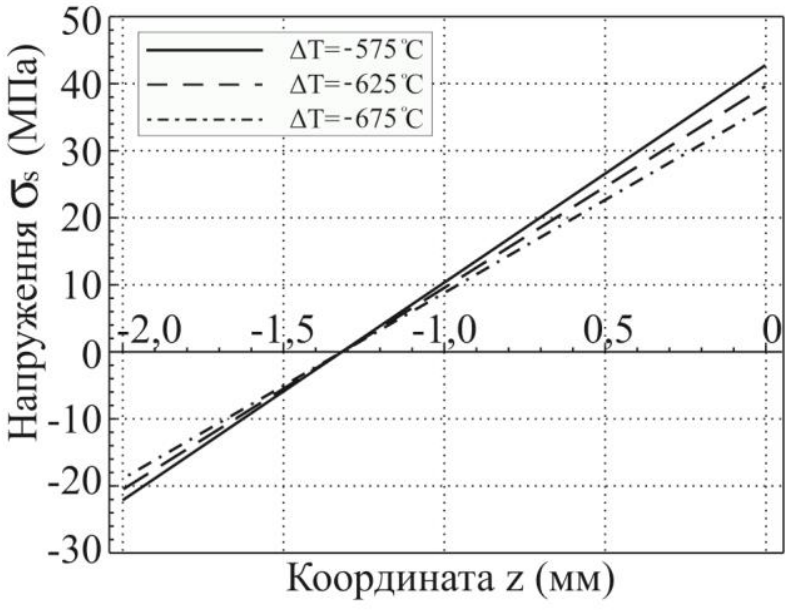

a

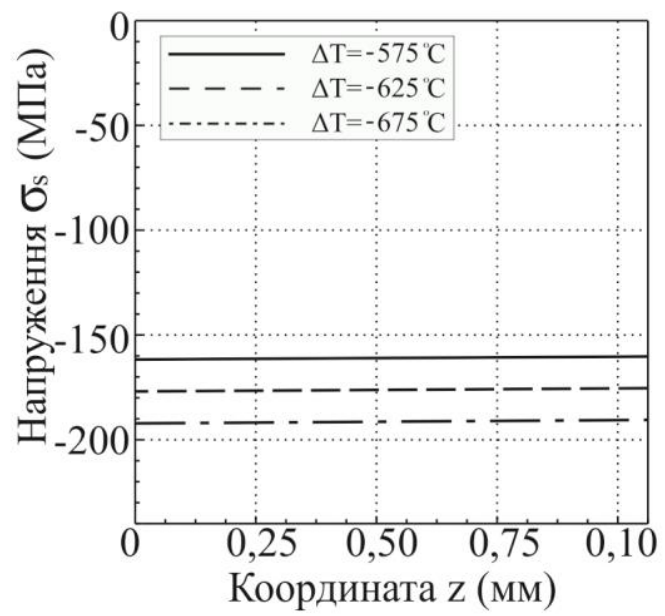

$\sigma$

Рис. 2 - Результати розрахунків термічних напружень:

а - термічні напруження в мідній підкладці;

б - термічні напруження в оксидному шарі

У результаті значної різниці значень КТР термічні напруження у певній мірі залежать від різниці температур, тобто від робочої температури процесу синтезу CuO. В оксидному шарі напруження завжди будуть стискальними, оскільки розглядається випадок $\alpha_{c}<\alpha_{s}$. Напруження в підкладці змінюється від розтягальних до стискальних у разі віддаленя від межі поділу покриття 3 підкладкою. Нейтральна вісь знаходиться на відстані від межі поділу z $\approx 1,3$ мм, що приблизно відповідає $z=-2 t_{s} / 3$. Схожі результати було отримано у роботах інших авторів [22].

\section{Висновки}

Незважаючи на те, що сумарні залишкові напруження в системі покриттяпідкладка залежать не лише від термічних напружень, розуміння величини і розподілу останніх в системі має вагоме значення для підвищення надійності та працездатності деталей з покриттями. Складнощі також пов'язані з визначенням 
дійсних модулів пружності та КТР ті впливу температури на них для одно- i багатошарових покриттів і покриттів із градієнтом властивостей по товщині. Проте навіть використання спрощених математичних моделей розрахунку напружень у покриттях та підкладках сприяє вдосконаленню процесу фрормування покриттів та підвищенню їх якості.

\section{Подяки}

Автор висловлює подяку Національному фонду досліджень України за підтримку (конкурс «Підтримка досліджень провідних та молодих учених», номер проєкту 2020.02/0119).

\section{Список літератури}

1. Low-pressure planar magnetron discharge for surface deposition and nanofabrication / O. Baranov, M. Romanov, M. Wolter, S. Kumar, X. Zhong, K. Ostrikov // Physics of Plasmas. - 2010. - Vol. 17. - P. 053509.

2. Plasma and Polymers: Recent Progress and Trends / I. Levchenko, Sh. Xu, O. Baranov, O. Bazaka, E. Ivanova, K. Bazaka // Molecules. - 2018. - Vol. 26. - iss. 13. - P. 4091. https://doi.org/10.3390/molecules26134091

3. Oxidation behavior and mechanism of MoSi2-Y2O3 composite coating fabricated by supersonic atmospheric plasma spraying / C.-C. Wang, K.-Z. Li, D.-Y. He, X.-H. Shi // Applied Surface Science. - 2020. - Vol. 506. - P. 144776. https://doi.org/10.1016/j.apsusc.2019.144776

4. Шоринов, А. В. Перспективы применения технологии холодного газодинамического напыления для защиты и восстановления деталей из магниевых сплавов [Текст] / А. В. Шоринов // Авиационно-космическая техника и технология. - 2018. - №2(146). - С. 20-27.

5. Physical vapor deposition technology for coated cutting tools: A review / Y. Deng, W. Chen, B. Li, C. Wang, T. Kuang, Y. Li // Ceramics International. - 2020. - Vol. 46. - $\quad$ iss. $11 . \quad-\quad$ P. $18373-18390$. https://doi.org/10.1016/j.ceramint.2020.04.168

6. A Review of Conductive Metal Nanomaterials as Conductive, Transparent, and Flexible Coatings, Thin Films, and Conductive Fillers: Different Deposition Methods and Applications / S. Naghdi, K. Y. Rhee, D. Hui, S. J. Park // Coatings. - 2018. - Vol. 8. - iss. 8. - P 278. https://doi.org/10.3390/coatings8080278

7. Naghdi, S. A Review of Conductive Metal Nanomaterials as Conductive, Transparent, and Flexible Coatings, Thin Films, and Conductive Fillers: Different Deposition Methods and Applications / S. Naghdi, K. Y. Rhee, D. Hui, S. J. Park // Coatings. - 2018. - Vol. 8. - iss 8. - P. 278. https://doi.org/10.3390/coatings8080278

8. Шорінов, О. В. Аналіз існуючих моделей виникнення напружень в тонких плівках і покриттях [Текст] / О. В. Шорінов // Відкриті інформаційні та комп'ютерні інтегровані технології. - 2021. - №91. - С. 77-96. https://doi.org/10.32620/oikit.2021.91.06

9. Review Article: Stress in thin films and coatings: Current status, challenges, and prospects / G. Abadias, E. Chason, J. Keckes, M. Sebastiani, G. B. Thompson, E. Barthel, G. L. Doll, C. E. Murray, C. H. Stoessel, L. Martinu // Journal of Vacuum Science \& Technology A. - Vol. 36. - P. 020801.

10. Marzbanrad, B. On the evolution of substrate's residual stress during cold spray process: A parametric study / B. Marzbanrad, H. Jahed, E. Toyserkani // 
Materials \& Design. - 2018. - Vol. 138. - P. 90-102. https://doi.org/10.1016/j.matdes.2017.10.062

11. Single-crystalline metal oxide nanostructures synthesized by plasmaenhanced thermal oxidation / B. Guo, M. Košiček, J. Fu, Y. Qu, G. Lin, O. Baranov, J. Zavašnik, Q. Cheng, K. Ostrikov, U. Cvelbar // Nanomaterials. - 2019. - Vol. 9. iss. 10. $P$ 1405. https://doi.org/10.3390/nano9101405

12. Dolmatov, A. I. Interaction of solid particles from a gas stream with the surface of a flat nozzle / A. I. Dolmatov, S. A. Polyviany // Metallofizika i Noveishie Tekhnologiithis. - Vol. 43. - iss. 3. - P. 319-328. https://doi.org/10.15407/mfint.43.03.0319

13. Canales, $\mathrm{H}$. Window of deposition description and prediction of deposition efficiency via machine learning techniques in cold spraying / $\mathrm{H}$. Canales, I. G. Cano, S. Dosta // Surface and Coatings Technology. -2020. - Vol. 401. - P. 126143. https://doi.org/10.1016/j.surfcoat.2020.126143

14. Stress Analysis and Failure Mechanisms of Plasma-Sprayed Thermal Barrier Coatings / J. Yang, L. Wang, D. Li, X. Zhong, H. Zhao, S. Tao // Journal of Thermal Spray Technology. - 2017. - Vol. 26. - P. 890-901. https://doi.org/10.1007/s11666-017-0544-7

15. Modeling and simulation of the temperature and stress fields in a 3D turbine blade coated with thermal barrier coatings / W. Zhu, J. W. Wang, L. Yang, Y. C. Zhou, Y. G. Wei, R. T. Wu // Surface and Coatings Technology. - 2017. - Vol. 315. - P. 443-453. https://doi.org/10.1016/j.surfcoat.2017.03.012

16. Bogdanovich, V. Calculation of residual stresses in plasma spray coatings taking into account the build-up process / V. Bogdanovich, M. Giorbelidze // Journal of Physics: Conference Series. - 2019. - Vol. 1368. - P. 042079. doi:10.1088/1742-6596/1368/4/042079

17. Wen, J. Examining the validity of Stoney-equation for in-situ stress measurements in thin film electrodes using a large-deformation finite-element procedure / J. Wen, Y. Wei, Y.-T. Cheng // Journal of Power Sources. - 2018. - Vol. 387. - P. 126-134. https://doi.org/10.1016/j.jpowsour.2018.03.052

18. Song, $Y$. Evolution of thermal stress in a coating/substrate system during the cooling process of fabrication / Y. Song, X. Zhuan, T. J. Wang, X. Chen // Mechanics of Materials. - 2014. - Vol. 74 . - P. 26-40. http://dx.doi.org/10.1016/j.mechmat.2014.03.006

19. Residual stresses in coating-based systems, part I: Mechanisms and analytical modeling / X. Zhang, Y. Wu, B. Xu, H. Wang // Frontiers of Mechanical Engineering in China. - 2007. - Vol. 2. - P. 1-12. http://dx.doi.org/10.1007/s11465007-0001-2

20. Effects of oxide thickness, $\mathrm{Al}_{2} \mathrm{O}_{3}$ interlayer and interface asperity on residual stresses in thermal barrier coatings / X. C. Zhang, B. S. Xu, H. D. Wang, Y. X. Wu // Mater Design. - 2006. - Vol. 27. - iss. 10. - P. 989-996. 10.1016/j.matdes.2005.02.008

21. Residual stresses in coating-based systems, part II: Optimal designing methodologies / X. Zhang, Y. Wu, B. Xu, H. Wang // Frontiers of Mechanical Engineering in China. - 2007. - Vol. 2. - iss. 2. - P. 125-136. https://doi.org/10.1007/s11465-007-0022-х

22. Баранов, О. О. Теоретична модель формування двовимірних наноструктур вертикального графену під дією плазми [Текст] / О. О. Баранов // Відкриті інформаційні та комп'ютерні інтегровані технології. - 2021. - №91. C. 122-142. https://doi.org/10.32620/oikit.2021.91.09 
23. Liu, N. Elastic constants and thermodynamic properties of $\mathrm{Cu}, \mathrm{Cu}_{2} \mathrm{O}$ and $\mathrm{CuO}$ from first-principles calculations / N. Liu, J. Sun, D. Wu // Advanced Materials Research. - 2011. - Vol. 335-336. - P. 328-332. doi:10.4028/www.scientific.net/AMR.335-336.328

\section{References}

1. Low-pressure planar magnetron discharge for surface deposition and nanofabrication / O. Baranov, M. Romanov, M. Wolter, S. Kumar, X. Zhong, K. Ostrikov // Physics of Plasmas. - 2010. - Vol. 17. - P. 053509.

2. Plasma and Polymers: Recent Progress and Trends / I. Levchenko, Sh. Xu, O. Baranov, O. Bazaka, E. Ivanova, K. Bazaka // Molecules. - 2018. - Vol. 26. - iss. 13. - P. 4091. https://doi.org/10.3390/molecules26134091

3. Oxidation behavior and mechanism of MoSi2-Y2O3 composite coating fabricated by supersonic atmospheric plasma spraying / C.-C. Wang, K.-Z. Li, D.-Y. He, X.-H. Shi // Applied Surface Science. - 2020. - Vol. 506. - P. 144776. https://doi.org/10.1016/j.apsusc.2019.144776

4. Shorinov, A. V. Perspektivy primeneniya tekhnologii kholodnogo gazodinamicheskogo napyleniya dlya zashchity $i$ vosstanovleniya detalei iz magnievykh splavov [Potential application of cold gas-dynamic spraying of protective and restorative coatings onto magnesium parts] / A. V. Shorinov // Aviatsionnokosmicheskaya tekhnika i tekhnologiya. - 2018. - no. 2. - iss. 146. - P. 20-27.

5. Physical vapor deposition technology for coated cutting tools: A review / Y. Deng, W. Chen, B. Li, C. Wang, T. Kuang, Y. Li // Ceramics International. - 2020. - Vol. 46. - iss. 11. - P. 18373-18390. https://doi.org/10.1016/j.ceramint.2020.04.168

6. A Review of Conductive Metal Nanomaterials as Conductive, Transparent, and Flexible Coatings, Thin Films, and Conductive Fillers: Different Deposition Methods anëd Applications / S. Naghdi, K. Y. Rhee, D. Hui, S. J. Park // Coatings. - 2018. - Vol. 8. - iss. 8. - P 278. https://doi.org/10.3390/coatings8080278

7. Naghdi, S. A Review of Conductive Metal Nanomaterials as Conductive, Transparent, and Flexible Coatings, Thin Films, and Conductive Fillers: Different Deposition Methods and Applications / S. Naghdi, K. Y. Rhee, D. Hui, S. J. Park // Coatings. - 2018. - Vol. 8. - iss 8. - P. 278. https://doi.org/10.3390/coatings8080278

8. Shorinov, O. V. Analiz isnuyuchykh modeley vynyknennya napruzhen' $v$ tonkykh plivkakh i pokryttyakh [Analysis of existing models of stress in thin films and coatings] / O. V. Shorinov // Otkrytye informatsionnye i komp'yuternye integrirovannye tekhnologii. - 2021. - no. 91. - P. 77-96. https://doi.org/10.32620/oikit.2021.91.06

9. Review Article: Stress in thin films and coatings: Current status, challenges, and prospects / G. Abadias, E. Chason, J. Keckes, M. Sebastiani, G. B. Thompson, E. Barthel, G. L. Doll, C. E. Murray, C. H. Stoessel, L. Martinu // Journal of Vacuum Science \& Technology A. - Vol. 36. - P. 020801.

10. Marzbanrad, B. On the evolution of substrate's residual stress during cold spray process: A parametric study / B. Marzbanrad, H. Jahed, E. Toyserkani // Materials \& Design. - 2018. - Vol. 138. - P. 90-102. https://doi.org/10.1016/j.matdes.2017.10.062

11. Single-crystalline metal oxide nanostructures synthesized by plasmaenhanced thermal oxidation / B. Guo, M. Košiček, J. Fu, Y. Qu, G. Lin, O. Baranov, J. Zavašnik, Q. Cheng, K. Ostrikov, U. Cvelbar // Nanomaterials. - 2019. - Vol. 9. iss. 10. P 1405. https://doi.org/10.3390/nano9101405 
12. Dolmatov, A. I. Interaction of solid particles from a gas stream with the surface of a flat nozzle / A. I. Dolmatov, S. A. Polyviany // Metallofizika i Noveishie Tekhnologiithis. - Vol. 43. - iss. 3. - P. 319-328. https://doi.org/10.15407/mfint.43.03.0319

13. Canales, $\mathrm{H}$. Window of deposition description and prediction of deposition efficiency via machine learning techniques in cold spraying / $\mathrm{H}$. Canales, I. G. Cano, S. Dosta // Surface and Coatings Technology. -2020. - Vol. 401. - P. 126143. https://doi.org/10.1016/j.surfcoat.2020.126143

14. Stress Analysis and Failure Mechanisms of Plasma-Sprayed Thermal Barrier Coatings / J. Yang, L. Wang, D. Li, X. Zhong, H. Zhao, S. Tao // Journal of Thermal Spray Technology. - 2017. - Vol. 26. - P. 890-901. https://doi.org/10.1007/s11666-017-0544-7

15. Modeling and simulation of the temperature and stress fields in a 3D turbine blade coated with thermal barrier coatings / W. Zhu, J. W. Wang, L. Yang, Y. C. Zhou, Y. G. Wei, R. T. Wu // Surface and Coatings Technology. - 2017. - Vol. 315. - P. 443-453. https://doi.org/10.1016/j.surfcoat.2017.03.012

16. Bogdanovich, V. Calculation of residual stresses in plasma spray coatings taking into account the build-up process / V. Bogdanovich, M. Giorbelidze // Journal of Physics: Conference Series. - 2019. - Vol. 1368. - P. 042079. doi:10.1088/1742-6596/1368/4/042079

17. Wen, J. Examining the validity of Stoney-equation for in-situ stress measurements in thin film electrodes using a large-deformation finite-element procedure / J. Wen, Y. Wei, Y.-T. Cheng // Journal of Power Sources. - 2018. - Vol. 387. - P. 126-134. https://doi.org/10.1016/j.jpowsour.2018.03.052

18. Song, $Y$. Evolution of thermal stress in a coating/substrate system during the cooling process of fabrication / Y. Song, X. Zhuan, T. J. Wang, X. Chen // Mechanics of Materials. - 2014. - Vol. 74. - P. 26-40. http://dx.doi.org/10.1016/j.mechmat.2014.03.006

19. Residual stresses in coating-based systems, part I: Mechanisms and analytical modeling / X. Zhang, Y. Wu, B. Xu, H. Wang // Frontiers of Mechanical Engineering in China. - 2007. - Vol. 2. - P. 1-12. http://dx.doi.org/10.1007/s11465007-0001-2

20. Effects of oxide thickness, $\mathrm{Al}_{2} \mathrm{O}_{3}$ interlayer and interface asperity on residual stresses in thermal barrier coatings / X. C. Zhang, B. S. Xu, H. D. Wang, Y. X. Wu // Mater Design. - 2006. - Vol. 27. - iss. 10. - P. 989-996. 10.1016/j.matdes.2005.02.008

21. Residual stresses in coating-based systems, part II: Optimal designing methodologies / X. Zhang, Y. Wu, B. Xu, H. Wang // Frontiers of Mechanical Engineering in China. - 2007. - Vol. 2. - iss. 2. - P. 125-136. https://doi.org/10.1007/s11465-007-0022-x

22. Baranov, O. O. Teoretychna model' formuvannya dvovymirnykh nanostruktur vertykal'noho hrafenu pid diyeyu plazmy [Theoretical model of formation of two-dimensional nanostructures of vertical graphene under the action of plasma] / O. О. Баранов // Otkrytye informatsionnye i komp'yuternye integrirovannye tekhnologii. - 2021. - no. 91. - P. 122-142. https://doi.org/10.32620/oikit.2021.91.09

23. Liu, N. Elastic constants and thermodynamic properties of $\mathrm{Cu}, \mathrm{Cu}_{2} \mathrm{O}$ and $\mathrm{CuO}$ from first-principles calculations / N. Liu, J. Sun, D. Wu // Advanced Materials Research. - 2011. - Vol. 335-336. - P. 328-332. doi:10.4028/www.scientific.net/AMR.335-336.328 


\section{An estimation of level of thermal stresses in oxide thin films}

The results of estimation of the nature and magnitude of residual thermal stresses in $\mathrm{CuO}$ oxide layer synthesized on a substrate of pure copper using a known analytical model for calculating thermal stresses in single-layer coatings are presented. Thermal stresses can lead to deformations and destruction of thin-film structures and coatings, shortages and reduced quality of parts on which they are applied. The main technological parameters, on which the values of thermal stresses depend, are the operating temperatures of the process of formation of thin-film oxide layers. After the synthesis process, the coated substrates are cooled to ambient temperature. This cooling leads to thermal residual stresses. In the case where the coefficient of thermal expansion of the material of the oxide layer is much less than the coefficient of thermal expansion of the substrate material, in the $\mathrm{CuO}$ layer compressive residual stresses generete, while in the Cu substrate - tensile stresses. The stress-strain state during the cooling of the thin film/substrate system, which is free from external forces, was investigated. The mathematical model used the assumption that the resulting deformations do not exceed the elastic limit (the residual stresses lie in the region of elastic deformations), and the temperature gradient in the thickness of the materials does not change. It should also be noted that the values of thermal expansion coefficients, modulus of elasticity and Poisson's ratios are constant values and do not depend on temperature changes. The paper presents the main analytical dependences of thermal stresses on the physical and mechanical properties of the coating materials and the substrate. Based on the results of calculations, a graph of the dependence of thermal stresses of the coatingsubstrate system depending on the temperature of synthesis of oxide layers was developed. Thermal stresses are one of the components of the total residual stresses operating in the film/coating system. The obtained results on the values of residual stresses can be used to prevent the deformation and failure of thin films and coatings, as well as to predict the characteristics of the surface layers.

Keywords: oxide layer, residual stress, coefficient of thermal expansion, coating.

\section{Відомості про автора:}

Шорінов Олександр Володимирович - кандидат технічних наук, доцент кафедри технології виробництва авіаційних двигунів, Національний аерокосмічний університет ім. М. Є. Жуковського «Харківський авіаційний інститут», м. Харків, Україна; o.shorinov@khai.edu; ResearchGate: OleksandrShorinov; ORCID: 0000-0002-5057-6679

\section{About the Author:}

Shorinov Oleksandr Volodymyrovych - Candidate of Technical Sciences, Senior Lecturer of Department of Aircraft Engine Manufacturing Technology, National Aerospace University "Kharkiv Aviation Institute", Kharkiv, Ukraine; o.shorinov@khai.edu; ResearchGate: Oleksandr-Shorinov; ORCID: 0000-00025057-6679 